COSTING:Journal of Economic, Business and Accounting

Volume 4 Nomor 2, Juni 2021

e-ISSN : 2597-5234

\title{
PENGARUH KEPEMILIKAN PUBLIK DAN PROFITABILITAS TERHADAP KETEPATAN WAKTU PENYAMPAIAN LAPORAN KEUANGAN
}

\section{THE INFLUENCE OF PUBLIC OWNERSHIP AND PROFITABILITY ON TIMELINESS FOR SUBMITTING FINANCIAL STATEMENTS}

\author{
Ida Fitriyani ${ }^{1}$, Dwi Indah Lestari ${ }^{2}$ \\ Jurusan Akuntansi, FEB, Unjani Cimahi, Indonesia ${ }^{1,2}$ \\ dwi.lestari@lecture.unjani.ac.id ${ }^{2}$
}

\begin{abstract}
This study aims to determine the effect of public ownership and profitability on the timeliness of financial report submission. Secondary data used in this research is the company's audited annual financial statements. The population in this study is mining sector companies listed on the Indonesia Stock Exchange 2014-2018. The sampling technique used in this research is purposive sampling, thereby obtained 180 samples from 36 companies. The analysis technique used in this research is logistic regression analysis. The results showed that the partial public ownership does not affect the timeliness of financial report submission, while profitability positive and significant impact on the timeliness of financial report submission. Public ownership and profitability simultaneously have a positive and significant effect on the timeliness of financial report submission.
\end{abstract}

Keywords: Public Ownership, Profitability and Timeliness of Financial Report Submission.

\begin{abstract}
ABSTRAK
Tujuan dari penelitian ini adalah untuk menganalisis pengaruh kepemilikan publik dan profitabilitas terhadap ketepatan waktu penyampaian laporan keuangan. Penelitian ini menggunakan data sekunder berupa laporan keuangan tahunan perusahaan yang telah diaudit. Peneliti memilih perusahaan sektor pertambangan yang terdaftar di Bursa Efek Indonesia Tahun 2014-2018 sebagai populasi dalam penelitian ini dimana teknik pengambilan sampel yang digunakan adalah purposive sampling. Berdasarkan kriteria yang telat ditetapkan diperoleh 180 sampel dari 36 perusahaan. Analisis regresi logistik digunakan dalam penelitian ini dan hasil analisis menunjukkan bahwa secara parsial kepemilikan publik tidak berpengaruh terhadap ketepatan waktu penyampaian laporan keuangan, sedangkan profitabilitas berpengaruh positif dan signifikan terhadap ketepatan waktu penyampaian laporan keuangan. Kepemilikan publik dan profitabilitas secara simultan berpengaruh positif dan signifikan terhadap ketepatan waktu penyampaian laporan keuangan.
\end{abstract}

Kata Kunci: Kepemilikan Publik, Profitabilitas dan Ketepatan Waktu Penyampaian Laporan Keuangan. 


\section{PENDAHULUAN}

Salah satu bentuk pertanggungjawaban perusahaan kepada stakeholders adalah dengan membuat Laporan Keuangan. Laporan keuangan akan menjadi sebuah informasi yang dapat digunakan pihak-pihak yang berkepentingan pada suatu perusahaan untuk mengetahui gambaran kondisi perusahaan sehingga mereka bisa mengambil keputusan secara cepat dan tepat.

Setiap perusahaan go public memiliki kewajiban yang sama untuk dapat menyampaikan laporan keuangan dimana dalam penyusunannya harus sesuai dengan Standar Akuntansi Keuangan yang ada dan kemudian laporan keuangan tersebut harus diaudit oleh akuntan publik yang sudah terdaftar di Badan Pengawas Pasar Modal (BAPEPAM). Ketepatan waktu penyampaian laporan keuangan akan berdampak pada tingkat manfaat dan nilai dari laporan keuangan tersebut. Apabila jarak waktu antara periode akuntansi (31 Desember) dengan tanggal penyampaian laporan keuangan semakin singkat, maka keuntungan yang di dapat dari laporan keuangan tersebut juga akan semakin banyak. Sebaliknya, apabila jarak antara periode akuntansi (31 Desember) dengan waktu penyampaian laporan keuangan semakin panjang, maka kemungkinan bocornya informasi pada pihak-pihak yang berkepentingan akan semakin tinggi (Hastutik, 2015). Oleh karena itu, ketepatan waktu penyampaian laporan keuangan sangat dibutuhkan oleh para pengguna laporan keuangan.

Tuntutan mengenai ketepatan waktu penyampaian laporan keuangan telah diatur oleh Bursa Efek Indonesia dalam Peraturan Kep-306/BEJ/07-2004 dan Surat Edaran Nomor: SE00004/BEI/08-2011. Bursa Efek Indonesia, dalam surat edaran tersebut menyatakan bahwa batas waktu Penyampaian Laporan Keuangan Auditan disesuaikan dengan Peraturan Bapepam dan LK Nomor X.K.2 tentang Penyampaian Laporan Keuangan Berkala Emiten Atau Perusahaan Publik. Dalam Peraturan Bapepam dan LK Nomor X.K.2, lampiran Keputusan Ketua Bapepam dan LK Nomor: KEP346/BL/2011 tentang Penyampaian Laporan Keuangan Berkala Emiten Atau Perusahaan Publik point 2c menyatakan bahwa Laporan keuangan tahunan wajib disampaikan kepada Bapepam dan LK dan diumumkan kepada masyarakat paling lambat pada akhir bulan ketiga (31 Maret) setelah tanggal laporan keuangan tahunan. Hal itu pun berlaku untuk penyampaian laporan keuangan tahunan Emiten atau Perusahaan Publik kepada Bursa Efek Indonesia yaitu paling lambat pada 90 hari (31 Maret) setelah tanggal periode laporan keuangan (31 Desember).

Apabila perusahaan tidak dapat menyampaikan laporan keuangan secara tepat waktu, maka perusahaan tersebut akan dikenakan sanksi sesuai peraturan yang ada dalam lampiran Keputusan Direksi PT Bursa Efek Jakarta Nomor: Kep-307/BEJ/07-2004 tentang Peraturan Nomor 1-H tentang Sanksi. Lampiran peraturan tersebut berisi mengenai sanksi-sanksi yang akan dikenakan khusus bagi Perusahaan Tercatat yang terlambat menyampaikan laporan keuangan. Dengan adanya peraturan mengenai batas waktu penyampaian laporan keuangan serta peraturan mengenai sanksinya, diharapkan setiap perusahaan dapat tepat waktu dalam menyampaikan laporan keuangan dan juga dapat mempertahankan relevansi atas informasi yang ada dalam laporan keuangan tersebut.

Namun apabila melihat pada kenyataan yang ada, masih banyak 
perusahaan-perusahaan yang tidak tepat waktu menyampaikan laporan keuangan tahunan. Berdasarkan hasil pemantauan Bursa Efek Indonesia, hingga tanggal 29 Juni 2019 terdapat 10 (sepuluh) Perusahaan Tercatat yang belum menyampaikan Laporan Keuangan Tahunan per 31 Desember 2018 dan/atau belum melakukan pembayaran denda atas keterlambatan penyampaian laporan keuangan. Hal tersebut tertera dalam nomor surat : 1) No.:Peng-SPT00011/BEI.PP1/07-2019, 2) No.:PengSPT-00006/BEI.PP2/07-2019, No.:Peng-SPT-00008/BEI.PP3/07-2019

Dari 10 (sepuluh) perusahaan tersebut, 3 (tiga) diantaranya merupakan perusahaan di sektor pertambangan yaitu PT Apexindo Pratama Duta Tbk (APEX), PT Borneo Lumbung Energi \& Metal Tbk (BORN), dan PT Cakra Mineral Tbk (CKRA). Ketiga perusahaan tersebut akhirnya dikenakan sanksi dimana PT Apexindo Pratama Duta Tbk (APEX) diberhentikan sementara perdagangan efek di Pasar Reguler dan Pasar Tunai sejak sesi I Perdagangan Efek tanggal 1 Juli 2019. kemudian, Bursa Efek Indonesia juga memperpanjang suspensi perdagangan efek untuk perusahaan PT Borneo Lumbung Energi \& Metal Tbk (BORN) dan PT Cakra Mineral Tbk (CKRA).

Selain itu, terdapat perusahaan lainnya di sektor pertambangan yang terlambat dalam penyampaian laporan keuangan tahunan kepada Bursa Efek Indonesia dengan rincian sebagai berikut :
Tabel 1 Perusahaan sektor pertambangan yang terlambat dalam penyampaian laporan keuangan tahun 2018

\begin{tabular}{clcc}
\hline No & $\begin{array}{l}\text { Nama Emiten atau } \\
\text { Perusahaan Publik }\end{array}$ & $\begin{array}{c}\text { Tanggal } \\
\text { Pelaporan }\end{array}$ & $\begin{array}{c}\text { Keterla } \\
\text { mbatan }\end{array}$ \\
\hline 1 & $\begin{array}{l}\text { PT Darma Henwa } \\
\text { Tbk (DEWA) }\end{array}$ & 10-Apr-19 & 10 hari \\
\hline 2 & $\begin{array}{l}\text { PT Cita Mineral } \\
\text { Investindo Tbk } \\
\text { (CITA) }\end{array}$ & 01-Apr-19 & 1 hari \\
\hline 3 & $\begin{array}{l}\text { PT Surya Esa Perkasa } \\
\text { Tbk (ESSA) }\end{array}$ & 03-Apr-19 & 3 hari \\
\hline Sumber : www.idx.co.id (data diolah) &
\end{tabular}

Fenomena-fenomena yang terjadi di atas menunjukan bahwa masih banyak perusahaan yang terdaftar di Bursa Efek Indonesia yang terlambat dalam menyampaikan laporan keuangan tahunannya kepada Bursa Efek Indonesia, salah satunya adalah perusahaan sektor pertambangan. Maka dari itu, perlu diketahui faktor-faktor apa saja yang dapat mempengaruhi ketepatan waktu perusahaan dalam penyampaian laporan keuangan tahunannya kepada publik. Beberapa penelitian yang telah dilakukan oleh peneliti-peneliti terdahulu telah berhasil menemukan faktor-faktor yang dapat mempengaruhi ketepatan waktu perusahaan dalam penyampaian laporan keuangannya. Bukti empiris yang ditemukan menyatakan bahwa keterlambatan perusahaan dalam menyampaikan laporan keuangan dikarenakan adanya berita buruk yang dialami perusahaan, seperti kesulitan keuangan yang dialami perusahaan, qualified opinion oleh auditor dan terjadinya keterlambatan audit (Valentina \& Gayatri, 2018).

Kemudian ditemukan juga faktor-faktor lain yang menjadi penentu ketepatan waktu penyampaian laporan keuangan dalam perusahaan antara lain profitabilitas, ukuran perusahaan, leverage, umur perusahaan dan struktur 
kepemilikan (Valentina \& Gayatri, 2018). Oleh karena itu, faktor-faktor yang akan di uji dalam penelitian ini adalah kepemilikan publik dan profitabilitas. Kedua faktor tersebut dipilih karena hasil penelitian terdahulu yang menggunakan variabel kepemilikian publik dan profitabilitas masih menghasilkan temuan penelitian yang berbeda.

Grand theory yang akan digunakan dalam penelitian ini adalah teori keagenan dan teori kepatuhan. Salah satu upaya untuk mengurangi asimetri informasi dalam hubungan keagenan adalah agen harus memberikan laporan keuangan kepada prinsipal secara periodik agar prinsipal dapat menilai kinerja agen serta kondisi perusahaan melalui laporan keuangan yang disampaikan yang mungkin dapat mempengaruhi keputusan investasi. Teori kepatuhan mendorong perusahaan agar dapat menyampaikan laporan keuangan secara tepat waktu melalui proses sosialisasi dan adanya pemberlakuan regulasi yang ketat (Saputra \& Ramantha, 2017).

Struktur kepemilikan didasarkan pada kepemilikan saham yang ada dalam perusahaan. Kepemilikan saham pada perusahaan terbagi menjadi dua, yaitu kepemilikan pihak dalam (insiders) dan kepemilikan pihak luar (outsiders). Pemilik perusahaan dari pihak luar memiliki kekuatan yang besar untuk dapat menekan manajemen agar dapat menyajikan informasi secara tepat waktu (Valentina \& Gayatri, 2018). Semakin besar persentase kepemilikan publik seharusnya membuat perusahaan dapat menyampaikan laporan keuangannya secara tepat waktu. Namun jika dilihat dari tabel 1 , ada ketidaksesuaian antara kenyataan dengan pernyataan tersebut. Seperti halnya yang terjadi pada perusahaan PT Darma Henwa Tbk
(DEWA), yang memiliki persentase kepemilikan publik hingga 71,04\%. Dengan persentase kepemilikan publik yang besar tersebut, PT Darma Henwa Tbk (DEWA) tidak dapat menyampaikan laporan keuangan tahun 2018 secara tepat waktu. Adapun perusahaan lain yang terlambat menyampaikan laporan keuangan tahun 2018 dengan persentase kepemilikan publik yang dimilikinya hanya sebesar 2,61\% yaitu PT Cita Mineral Investindo Tbk (CITA). Dengan persentase kepemilikan publik yang lebih rendah, PT Cita Mineral Investindo Tbk (CITA) mampu menyampaikan laporan keuangan kepada publik lebih cepat dibandingkan dengan PT Darma Henwa Tbk (DEWA).

Sementara itu, profitabilitas merupakan salah satu alat ukur yang digunakan untuk menilai bagaimana kinerja suatu perusahaan serta dapat menunjukkan tingkat kemampuannya dalam menghasilkan laba pada periode, tingkat penjualan, serta aset dan modal saham tertentu (Andriana \& Raspati, 2015). Kondisi profitabilitas yang tinggi pada suatu perusahaan menjadi berita baik (good news) yang harus dan ingin segera disampaikan perusahaan kepada publik (Andriana \& Raspati, 2015). Namun, perusahaan PT Surya Esa Perkasa Tbk (ESSA) tetap tidak dapat menyampaikan laporan keuangan tahun 2018 secara tepat waktu meskipun memiliki persentase Return on Assets (ROA) yang tinggi yaitu sebesar 5,64\%. Jika dilihat dari fenomena-fenomena di atas, ada ketidaksesuaian antara teori dengan kejadian yang sebenarnya karena banyak perusahaan yang masih terlambat dalam menyampaikan laporan keuangan tahunannya. 


\section{METODE PENELITIAN}

Penelitian ini menggunakan metode penelitian kuantitatif. Populasi yang digunakan dalam penelitian ini adalah perusahaan sektor pertambangan yang terdaftar di Bursa Efek Indonesia (BEI) selama tahun 2014-2018 yang berjumlah 48 perusahaan. Teknik pengambilan sampel yang digunakan dalam penelitian ini adalah Nonprobability Sampling dengan metode sampling purposive. Adapun kriteria atau pertimbangan yang digunakan peneliti dalam pemilihan sampel penelitian ini adalah sebagai berikut :

1. Perusahaan sektor pertambangan yang terdaftar di Bursa Efek Indonesia (BEI) selama tahun 2014-2018.

2. Perusahaan yang menerbitkan laporan keuangan tahunan secara lengkap dan sedang tidak di suspensi ataupun delisting tahun 2014-2018.

Berdasarkan kriteria data diatas, maka jumlah perusahaan yang dapat digunakan sebagai sampel dalam penelitian ini adalah sebanyak 36 perusahaan sektor pertambangan yang terdaftar di Bursa Efek Indonesia tahun 2014-2018, sehingga didapatkan jumlah sampel sebanyak $36 \times 5$ tahun $=180$ sampel. Variabel independen terdiri dari kepemilikan publik yang diukur dengan persentase kepemilikan publik dan profitabilitas diukur dengan ROA. Sedangkan variabel dependen diukur dengan melihat tanggal penyampaian laporan keuangan tahunan ke BEI, yaitu dengan menggunakan variabel dummy dengan kategori $1=$ tepat waktu dan $0=$ tidak tepat waktu.

Hipotesis akan diuji menggunakan analisis regresi logistik, oleh karena itu peneliti akan menggunakan analisis statistik deskriptif, analisis regresi logistik, menilai kelayakan model regresi, menilai overall model fit, koefisien determinasi, serta penarikan kesimpulan dengan Uji Wald (Parsial) dan Uji Omnibus Test of Model Coefficients (Simultan).

\section{HASIL DAN PEMBAHASAN}

Statistik deskriptif digunakan untuk memberikan gambaran dan mendeskripsikan suatu data yang dilihat dari nilai minimum, maksimum, ratarata (mean) dan standar deviasi yang dihasilkan dari setiap variabel penelitian.

Tabel 2 Statistik Deskriptif

Descriptive Statistics

\begin{tabular}{lccccc}
\hline & $\mathrm{N}$ & Min & Max & Mean & $\begin{array}{c}\text { Std. } \\
\text { Deviation }\end{array}$ \\
\hline KP & 180 & .024 & .854 & .30544 & .181734 \\
\hline PRO & 180 & -.721 & .456 & .01681 & .128322 \\
\hline $\begin{array}{l}\text { Valid N } \\
\text { (listwise) }\end{array}$ & 180 & & & & \\
\hline $\begin{array}{l}\text { Sumber : Hasil Pengolahan Data dengan SPSS 25, } \\
\text { 2020 } \\
\text { Berdasarkan }\end{array}$ & $\begin{array}{c}\text { tabel } \\
\text { pada }\end{array}$ & 2 & $\begin{array}{c}\text { dapat } \\
\text { variabel }\end{array}$
\end{tabular}

kepemilikan publik menunjukkan nilai minimum sebesar 0.024 dan nilai maksimum sebesar 0.854. Rata-rata (mean) variabel kepemilikan publik adalah sebesar 0.30544 dengan standar deviasi sebesar 0.181734. Hal ini menunjukkan bahwa rata-rata kepemilikan publik yang ada pada perusahaan sampel adalah sebesar $30,54 \%$. Kemudian nilai minimum pada variabel profitabilitas adalah sebesar 0.721 dan nilai maksimum sebesar 0.456 . Rata-rata (mean) pada variabel profitabilitas adalah sebesar 0.01681 dengan standar deviasi sebesar 0.128322 . Hal ini menunjukkan bahwa rata-rata keberhasilan yang dicapai perusahaan sampel dalam menghasilkan laba bersih atas pemanfaatan aset yang dimiliki adalah sebesar 1,68\%. Variabel ketepatan waktu penyampaian laporan 
keuangan tidak dapat diikutsertakan dalam perhitungan statistik deskriptif karena variable tersebut menggunakan skala nominal yang hanya berfungsi sebagai label kategori semata tanpa nilai intrinsik dan tidak memiliki arti apaapa, sehingga tidak tepat jika menghitung rata-rata (mean) dan standar deviasi dari variabel tersebut (Ghozali, 2018:4).

Uji kelayakan model regresi dilakukan untuk mengetahui apakah hipotesis nol dari data empiris telah cocok atau sesuai dengan model atau tidak (tidak ada perbedaan antara model dengan data sehingga model dapat dikatakan fit). Hasil pengujian tersebut diperoleh dengan menggunakan Hosmer and Lemeshow's Goodness of Fit Test. Berikut ini disajikan hasil pengujian kelayakan model regresi :

Tabel 3 Menilai Kelayakan Model Regresi

\section{Hosmer and Lemeshow Test}

\begin{tabular}{|c|c|c|c|}
\hline Step & Chi-square & $\mathrm{df}$ & Sig. \\
\hline 1 & 3.882 & 8 & .868 \\
\hline
\end{tabular}

Berdasarkan tabel 3 diatas, dapat dilihat bahwa nilai Chi-square adalah sebesar 3.882 dengan nilai Sig. sebesar 0.868. Dengan hasil tersebut dapat diketahui bahwa nilai signifikansi lebih besar dari 0.05. Artinya, model mampu memprediksi nilai observasinya dan model dapat diterima karena cocok atau telah sesuai dengan data observasinya. Hal ini berarti bahwa model regresi logistik ini layak digunakan untuk analisis selanjutnya karena tidak ada perbedaan yang signifikan antara model dengan nilai observasinya.

Menilai keseluruhan model (overall model fit) dilakukan dengan membandingkan nilai antara -2 Log Likelihood (-2LL) pada awal (Block
Number $=0$ ) dengan nilai -2 Log Likelihood (-2LL) pada akhir (Block Number $=1$ ). Apabila terjadi penurunan nilai -2LL maka model yang dihipotesiskan telah fit dengan data. Berikut ini adalah hasil pengujian menilai keseluruhan model (overall model fit) :

Tabel 4 Menilai Keseluruhan Model

Block 0: Beginning Block Iteration History ${ }^{\mathrm{a}, \mathrm{b}, \mathrm{c}}$

\begin{tabular}{llrr}
\hline & \multicolumn{2}{c}{$\begin{array}{c}\text { Log } \\
\text { Iteration }\end{array}$} & \multicolumn{1}{c}{ Coefficients } \\
\cline { 3 - 4 } Step 0 & 1 & 214.725 & Constant \\
\cline { 2 - 4 } & 2 & 214.587 & .867 \\
\cline { 2 - 4 } & 3 & 214.587 & .927 \\
\hline
\end{tabular}

Block 1: Method = Enter Iteration History $^{\mathbf{a}, \mathbf{b}, \mathbf{c}, \mathbf{d}}$

\begin{tabular}{lrrrrr}
\hline & \multicolumn{2}{c}{-2 Log } & \multicolumn{3}{c}{ Coefficients } \\
\cline { 3 - 6 } Iteration & likelihood & Constant & KP & PRO \\
\hline Step 1 & 1 & 199.914 & .919 & -.389 & 3.962 \\
\cline { 2 - 6 } & 2 & 198.185 & 1.077 & -.613 & 5.570 \\
\cline { 2 - 6 } & 3 & 198.136 & 1.097 & -.660 & 5.941 \\
\cline { 2 - 6 } & 4 & 198.136 & 1.097 & -.662 & 5.955 \\
\cline { 2 - 6 } & 5 & 198.136 & 1.097 & -.662 & 5.955 \\
\hline Sumber: Hasil Pengolahan Data dengan SPSS 25, \\
2020
\end{tabular}

Dari hasil pengujian menilai keseluruhan model (overall model fit) pada tabel 4 dapat diketahui bahwa nilai -2 Log Likelihood (-2LL) pada awal (block number $=0$ ) adalah sebesar 214.587 dan setelah variabel bebas dimasukkan pada model regresi maka nilai -2 Log Likelihood (-2LL) memiliki nilai akhir (block number $=1$ ) sebesar 198.136. Berdasarkan output tersebut dapat dilihat bahwa terjadinya penurunan nilai -2 Log Likelihood (-2LL). Artinya, keseluruhan model yang dihipotesiskan telah cocok ( $f i t)$ dengan data penelitian dan terbukti bahwa penambahanpenambahan variabel independen yaitu kepemilikan publik dan profitabilitas ke dalam model penelitian ini dapat memperbaiki model sehingga dapat 
menghasilkan model regresi yang lebih baik.

Uji koefisien determinasi digunakan untuk mengetahui seberapa besar variabel independen yang digunakan dalam penelitian ini, yaitu kepemilikan publik dan profitabilitas berpengaruh terhadap variabel dependen. Dengan melihat nilai Nagelkerke's $R$ Square, maka dapat diketahui besarnya nilai koefisien determinasi pada model regresi logistik dalam penelitian ini. Berikut merupakan hasil pengujian koefisien determinasi :

Tabel 5 Koefisien Determinasi

\begin{tabular}{lccc}
\multicolumn{4}{c}{ Model Summary } \\
\hline Step & $\begin{array}{c}-2 \text { Log } \\
\text { likelihood }\end{array}$ & $\begin{array}{c}\text { Cox \& Snell R } \\
\text { Square }\end{array}$ & $\begin{array}{c}\text { Nagelkerke R } \\
\text { Square }\end{array}$ \\
\hline 1 & $198.136^{\mathrm{a}}$ & .087 & .125 \\
\hline
\end{tabular}

Sumber : Hasil Pengolahan Data dengan SPSS 25 , 2020

Berdasarkan tabel 5 diatas dapat dilihat bahwa nilai Nagelkerke's $R$ Square yang diperoleh dalam penelitian ini adalah sebesar 0.125. Nilai ini menunjukkan bahwa variabel independen dalam penelitian ini secara bersama-sama hanya mampu menjelaskan $12,5 \%$ variabilitas variabel dependen, sedangkan sisanya sebesar $87,5 \%$ variabilitas variabel dependen dapat dijelaskan oleh variabel-variabel selain yang ada didalam model penelitian ini.

Untuk penarikan kesimpulan pada analisis regresi logistik menggunakan uji wald dan uji omnibus. Uji wald dilakukan untuk mengetahui ada atau tidak pengaruh dari variabel independen terhadap variabel dependen secara parsial dengan membandingkan nilai signifikansi dengan alpha sebesar $5 \%$ atau $\alpha=0.05$.
Tabel 6 Uji Wald (Parsial)

\begin{tabular}{|c|c|c|c|c|c|c|}
\hline & & B & S.E. & Wald & $\mathrm{df}$ & Sig. \\
\hline \multirow[t]{3}{*}{ Step $1^{\mathrm{a}}$} & KP & -.662 & .966 & .469 & 1 & .493 \\
\hline & PRO & 5.955 & 1.886 & 9.967 & 1 & .002 \\
\hline & Constant & 1.097 & .354 & 9.602 & 1 & .002 \\
\hline
\end{tabular}

Sumber : Hasil Pengolahan Data dengan SPSS 25, 2020

Berdasarkan tabel 6 di atas terlihat bahwa hasil pengujian hipotesis regresi logistik dalam penelitian ini ada pada tingkat signifikansi $5 \%$ atau 0.05 . Model persamaan regresi logistik yang terbentuk dalam penelitian ini adalah sebagai berikut :

$$
\begin{gathered}
\operatorname{Ln} \frac{K W P L K}{1-K W P L K}=1.097-0.662 \mathrm{KP}+5.955 \mathrm{P} \\
+\epsilon
\end{gathered}
$$

Dari model regresi tersebut dapat dijelaskan bahwa :

1. Nilai dari $\alpha$ (konstanta) sebesar 1.097 menunjukkan bahwa, pada saat semua variabel independen yaitu kepemilikan publik dan profitabilitas memiliki nilai 0, maka variabel dependen yaitu ketepatan waktu penyampaian laporan keuangan memiliki probabilitas meningkat sebesar 1.097.

2. Nilai dari koefisien regresi variabel kepemilikan publik adalah sebesar -0.662. Hal tersebut menunjukkan, pada saat kepemilikan publik memiliki nilai 1 sedangkan variabel independen lainnya yaitu profitabilitas memiliki nilai 0 , maka variabel dependen yaitu ketepatan waktu penyampaian laporan keuangan memiliki probabilitas menurun sebesar 0.662 .

3. Nilai dari koefisien regresi variabel profitabilitas adalah sebesar 5.955 yang menunjukkan bahwa, ketika profitabilitas memiliki nilai 1 sedangkan variabel independen lainnya yaitu kepemilikan publik memiliki nilai 0 , maka variabel 
dependen yaitu ketepatan waktu penyampaian laporan keuangan memiliki probabilitas meningkat sebesar 5.995.

Hasil dari pengujian hipotesis dapat dilihat pada tabel 6 , dengan hasil sebagai berikut :

\section{Variabel $X_{1}$ (Kepemilikan Publik)}

Berdasarkan hasil pengujian hipotesis secara parsial yang dilihat pada tabel 6 di atas, nilai signifikansi yang diperoleh variabel kepemilikan publik mempunyai tingkat probabilitas signifikansi lebih dari 0.05 yaitu sebesar 0.493. Artinya, dapat dinyatakan bahwa $\mathbf{H}_{\mathbf{0 1}}$ diterima dan $\mathbf{H}_{\mathbf{a} 1}$ ditolak. Dengan demikian dapat disimpulkan bahwa kepemilikan publik tidak berpengaruh secara signifikan terhadap variabel dependen yaitu ketepatan waktu penyampaian laporan keuangan.

Hal ini berarti bahwa besar kecilnya persentase kepemilikan publik pada suatu perusahaan tidak dapat dijadikan acuan bahwa perusahaan dengan kepemilikan publik yang besar akan selalu menyampaikan laporan keuangannya secara tepat waktu. Begitupun dengan perusahaan yang memiliki persentase kepemilikan publik yang kecil tidak selalu terlambat dalam menyampaikan laporan keuangannya. Semua perusahaan dengan persentase kepemilikan publik yang tinggi maupun rendah memiliki keinginan yang sama dan kewajiban yang sama untuk menyampaikan laporan keuangan perusahaannya sedini mungkin kepada publik.

Seperti yang terjadi di perusahaan sampel pada penelitian ini yang memiliki persentase kepemilikan publik dengan rata-rata jumlahnya sebesar $25 \%$, tetap tidak dapat memberikan pengaruh yang kuat kepada pemegang saham untuk dapat mengawasi perusahaan agar menyampaikan laporan keuangan secara tepat waktu. Hal ini disebabkan karena persentase kepemilikan publik sebesar apapun dalam suatu perusahaan tetap terpecah menjadi persentase yang kecil, sehingga kekuatan para pemegang saham untuk mengontrol tindakan manajemen pun menjadi terbatas.

Sebagai contoh perusahaan dalam sampel yaitu PT Dian Swastatika Sentosa Tbk (DSSA) yang memiliki tingkat persentase kepemilikan publik yang tinggi dan konsisten selama 5 tahun sebesar $40.10 \%$ dan PT Bayan Resources Tbk (BYAN) yang memiliki tingkat persentase kepemilikan publik yang rendah yaitu pada tahun 20142017 sebesar 4.98\% dan tahun 2018 sebesar 3.71\%. Kedua perusahaan tersebut memiliki tingkat persentase kepemilikan publik yang berbeda, namun kedua perusahaan tersebut secara konsisten dapat menyampaikan laporan keuangan secara tepat waktu. Hal ini menunjukkan bahwa perusahaan dengan tingkat persentase kepemilikan publik yang rendah masih memiliki kemungkinan untuk dapat menyampaikan laporan keuangan secara tepat waktu seperti perusahaan dengan tingkat persentase kepemilikan publik yang tinggi. Berdasarkan bukti dari sampel perusahaan tersebut maka dapat ditarik kesimpulan bahwa besar kecil persentase kepemilikan publik tidak dapat mempengaruhi ketepatan waktu perusahaan dalam menyampaikan laporan keuangan.

Hasil penelitian ini sejalan dengan penelitian yang dilakukan oleh Andriana \& Raspati (2015), yang menyatakan bahwa kepemilikan publik tidak berpengaruh terhadap ketepatan waktu penyampaian laporan keuangan. Hal tersebut dikarenakan beberapa perusahaan yang menjadi sampel dalam penelitian baik yang memiliki tingkat 
kepemilikan publik tinggi maupun rendah memiliki mekanisme pengawasan internal dan juga sudah memiliki reputasi yang baik dimata publik sehingga perusahaan harus menjaga reputasi tersebut.

Akan tetapi hasil penelitian ini bertentangan dengan hasil penelitian yang dilakukan oleh Hadi (2018), yang menyatakan bahwa kepemilikan publik berpengaruh signifikan terhadap ketepatan waktu penyampaian laporan keuangan. Alasan dari hasil penelitian ini adalah kepemilikan publik baik dengan kapasitas banyak maupun sedikit akan menjamin ketepatan waktu penyampaian laporan keuangan dari perusahaan tersebut, dimana hal tersebut tidak ditemukan pada sampel penelitian yang peneliti ambil.

\section{Variabel $X_{2}$ (Profitabilitas)}

Berdasarkan hasil pengujian hipotesis secara parsial yang dilihat pada tabel 6 di atas, nilai signifikansi yang diperoleh variabel profitabilitas mempunyai tingkat probabilitas signifikansi kurang dari 0.05 yaitu sebesar 0.002. Artinya, dapat dinyatakan bahwa $\mathrm{H}_{01}$ ditolak dan $\mathrm{H}_{\mathrm{a} 1}$ berhasil diterima. Dengan demikian dapat disimpulkan bahwa terdapat pengaruh positif dan signifikan antara profitabilitas terhadap ketepatan waktu penyampaian laporan keuangan.

Tingkat profitabilitas yang besar cenderung membuat perusahaan dapat tepat waktu dalam menyampaikan laporan keuangannya karena perusahaan ingin mendapatkan penilaian yang baik dari para pengguna laporan keuangan. Begitupun sebaliknya, apabila perusahaan memiliki tingkat profitabilitas yang kecil maka perusahaan akan cenderung terlambat dalam menyampaikan laporan keuangannya karena lebih berhati-hati dalam menyajikan laporan keuangannya.

Hal tersebut dapat terbukti dari beberapa sampel perusahaan seperti yang terjadi pada PT Ratu Prabu Energi Tbk (ARTI) yang merupakan perusahaan dengan tingkat persentase profitabilitas (ROA) rendah yaitu $<2 \%$ setiap tahunnya. Hal tersebut mempengaruhi perusahaan dalam menyampaikan laporan keuangan menjadi tidak tepat waktu selama 5 tahun waktu penelitian. Sedangkan PT Samindo Resources Tbk (MYOH) dapat menyampaikan laporan keuangannya secara tepat waktu dikarenakan perusahaan memiliki tingkat profitabilitas yang tinggi yaitu sebesar lebih dari $9 \%$ bahkan di beberapa tahun mencapai 20\%. Hal tersebut membuktikan bahwa besar kecilnya persentase profitabilitas dapat mempengaruhi ketepatan waktu perusahaan dalam menyampaikan laporan keuangan.

Hasil penelitian ini sejalan dengan penelitian yang dilakukan oleh Astuti \& Erawati (2018), Pujiatmi \& Ismawati (2018) dan Aldrian \& Nadirysah (2019), yang menyatakan bahwa profitabilitas berpengaruh positif dan signifikan terhadap ketepatan waktu penyampaian laporan keuangan perusahaan. Alasan dari hasil penelitian ini dikarenakan tingkat profitabilitas yang tinggi merupakan berita baik bagi perusahaan yang harus segera disampaikan kepada publik. Tingkat profitabilitas yang tinggi menunjukkan kinerja manajemen yang baik sehingga mempengaruhi keinginan manajemen untuk dapat segera menyampaikan laporan keuangannya. Hal tersebut dilakukan karena agen ingin dipercaya oleh para prinsipal untuk jangka waktu yang panjang. Perusahaan yang mampu menghasilkan profit tinggi akan cenderung lebih tepat waktu dalam 
menyampaikan laporan keuangannya karena memiliki tujuan salah satunya adalah menarik kepercayaan para investor untuk menanamkan modalnya di perusahaan. Apabila perusahaan memiliki tingkat profitabilitas rendah maka hal tersebut menjadi berita buruk bagi perusahaan sehingga penyampaian laporan keuangan cenderung ditunda karena dikhawatirkan akan menyebabkan para investor berpikir ulang untuk menanamkan sahamnya di perusahaan tersebut.

Hasil penelitian ini bertentangan dengan hasil penelitian yang dilakukan oleh Dewayani et al., (2017), menyatakan bahwa profitabilitas tidak berpengaruh terhadap ketepatan waktu penyampaian laporan keuangan. Alasan dari penelitian ini adalah karena perusahaan dengan tingkat profitabilitas rendah bisa jadi tepat waktu dalam menyampaikan laporan keuangannya. Hal ini dikarenakan perusahaan tidak ingin mendapat denda sehingga perusahaan harus mengeluarkan biaya dan juga perusahan dapat kehilangan kepercayaan dari masyarakat apabila tidak menyampaikan laporan keuangannya secara tepat waktu.

Untuk mengetahui pengaruh variabel-variabel independen yang terdiri dari kepemilikan publik dan profitabilitas secara simultan pada analisis regresi logistik dilakukan uji omnibus sehingga dapat diketahui berpengaruh atau tidaknya variabel independen terhadap variabel dependen yaitu ketepatan waktu penyampaian laporan keuangan. Berikut merupakan hasil dari pengujian tersebut :
Tabel 7 MUji Omnibus Test of Model Coefficients (Simultan)

Omnibus Tests of Model Coefficients

\begin{tabular}{llrrr}
\hline & & Chi-square & df & \multicolumn{1}{c}{ Sig. } \\
\hline Step 1 & Step & 16.450 & 2 & .000 \\
\cline { 2 - 5 } & Block & 16.450 & 2 & .000 \\
\cline { 2 - 5 } & Model & 16.450 & 2 & .000 \\
\multirow{2}{*}{ Sumber } & $\begin{array}{l}\text { Hasil Pengolahan Data dengan SPSS } \\
\text { 25, 2020 }\end{array}$ & &
\end{tabular}

Berdasarkan tabel 7 di atas dapat dilihat bahwa nilai Chi-square yang dihasilkan sebesar 16.450, dengan nilai signifikansi $<0.05$ yaitu sebesar 0.000 . Dengan demikian, dapat disimpulkan bahwa variabel independen yaitu kepemilikan publik dan profitabilitas secara simultan berpengaruh positif dan signifikan terhadap variabel dependen yaitu ketepatan waktu penyampaian laporan keuangan. Artinya, setiap perubahan yang terjadi pada variabel independen pada penelitian ini yaitu kepemilikan publik dan profitabilitas secara simultan akan mempengaruhi ketepatan waktu penyampaian laporan keuangan pada perusahaan pertambangan yang terdaftar di Bursa Efek Indonesia Tahun 2014-2018.

\section{PENUTUP \\ Kesimpulan}

Berdasarkan hasil analisis data dan pengujian hipotesis pada bab sebelumnya, dapat disimpulkan bahwa secara keseluruhan hasil pengamatan mengenai pengaruh kepemilikan publik dan profitabilitas terhadap ketepatan waktu penyampaian laporan keuangan pada perusahaan pertambangan yang terdaftar di Bursa Efek Indonesia tahun 2014-2018 adalah sebagai berikut :

1. Ketepatan waktu penyampaian laporan keuangan pada perusahaan pertambangan yang terdaftar di Bursa Efek Indonesia tahun 20142018 menunjukkan bahwa mayoritas 
perusahaan sudah tepat waktu dalam menyampaikan laporan keuangannya, hal ini ditunjukkan dengan jumlah 129 data sampel dan sisanya sebanyak 51 data sampel tidak tepat waktu.

2. Kepemilikan publik pada perusahaan pertambangan yang terdaftar di Bursa Efek Indonesia tahun 20142018 menunjukkan bahwa sebanyak 113 data sampel memiliki persentase kepemilikan publik diatas $25 \%$ dan sisanya sebanyak 67 data sampel memiliki persentase kepemilikan publik dibawah $25 \%$.

3. Profitabilitas pada perusahaan pertambangan yang terdaftar di Bursa Efek Indonesia tahun 20142018 menunjukkan bahwa sebanyak 101 data sampel memiliki nilai profitabilitas di atas rata-rata industri dan sisanya sebanyak 79 data sampel memiliki nilai profitabilitas di bawah rata-rata industri selama tahun penelitian.

4. Secara parsial kepemilikan publik tidak berpengaruh terhadap ketepatan waktu penyampaian laporan keuangan, sedangkan profitabilitas berpengaruh positif dan signifikan terhadap ketepatan waktu penyampaian laporan keuangan. Secara simultan atau bersama-sama kepemilikan publik dan profitabilitas berpengaruh positif dan signifikan terhadap ketepatan waktu penyampaian laporan keuangan.

\section{Saran}

Berdasarkan pembahasan yang telah dilakukan sebelumnya, peneliti bermaksud memberikan saran yang diharapkan dapat melengkapi keterbatasan dalam penelitian ini, antara lain :

1. Peneliti selanjutnya perlu mempertimbangkan untuk mengganti atau menambah variabel independen lain yang mungkin dapat berpengaruh terhadap ketepatan waktu penyampaian laporan keuangan seperti leverage, ukuran perusahaan, umur perusahaan, likuiditas, kepemilikan manajerial dan opini audit.

2. Peneliti selanjutnya disarankan untuk melakukan penelitian pada perusahaan di sektor lain untuk mengetahui hasil penelitian yang lebih variatif dan lebih akurat selain pada perusahaan pertambangan yang terdaftar di Bursa Efek Indonesia.

\section{DAFTAR PUSTAKA}

Andriana, D., \& Raspati, N. A. (2015). Pengaruh Profitabilitas dan Kepemilikan Publik terhadap Ketepatan Waktu Penyampaian Laporan Keuangan. Jurnal Riset Akuntansi dan Keuangan, 3(2), 649-659.

Astuti, W., \& Erawati, T. (2018). Pengaruh Profitabilitas, Umur Perusahaan dan Ukuran Perusahaan terhadap Ketepatan Waktu Penyampaian Laporan Keuangan Perusahaan ( Studi pada Perusahaan Manufaktur Yang Terdaftar di Bursa Efek Indonesia Tahun 2012-2016 ). Jurnal Kajian Bisnis, 26(2), 144-157.

Dewayani, M. A., Amin, M. Al, \& Dewi, V. S. (2017). Analisis Faktor-Faktor Yang Memengaruhi Ketepatan Waktu Pelaporan Keuangan ( Studi Empiris pada Perusahaan Manufaktur yang Terdaftar di Bursa Efek Indonesia Periode 2011-2016).University Research Colloquium, 441-458. 
Diliasmara, D. A., \& Nadirsyah, N. (2019). Pengaruh Profitabilitas, Likuiditas, Financial Leverage, dan Struktur Kepemilikan Terhadap Ketepatan Waktu Pelaporan Keuangan Pada Perusahaan Manufaktur Yang Terdaftar di Bursa Efek Indonesia pada Tahun 20132015. Jurnal Ilmiah Mahasiswa Ekonomi Akuntansi, 4(2), 304316.

https://doi.org/10.24815/jimeka. v4i2.12257

Hadi, M. (2018). Determinan Ketepatan Waktu Penyampaian Laporan Keuangan Perusahaan Manufaktur di Indonesia. Jurnal Riset Akuntansi dan Perpajakan, 5(1), 77-85.

Hastutik, S. (2015). Pengaruh Profitabilitas, Likuiditas, Struktur Kepemilikan, Ukuran Perusahaan dan Opini Audit Terhadap Ketepatan Waktu Pelaporan Keuangan Perusahaan. Jurnal Akuntansi dan Sistem Teknologi Informasi, 11 , 102-111. https://doi.org/10.1017/CBO978 1107415324.004

Pujiatmi, \& Ismawati, K. (2018). Faktor Yang Mempengaruhi Ketepatan Waktu Pelaporan Keuangan. Jurnal Ilmu Dan Riset Akuntansi, 7(1), 43-76. https://doi.org/10.15408/akt.v9i1 .3589

Saputra, K. W. S., \& Ramantha, I. W. (2017). Pengaruh Profitabilitas dan Ukuran Perusahaan Terhadap Ketepatan Waktu Pelaporan Keuangan Dengan Opini Audit Sebagai Pemoderasi. Jurnal Akuntansi Universitas Udayana, 20(2), 2302-8556.
Valentina, I. B., \& Gayatri. (2018). Pengaruh Profitabilitas, Ukuran Perusahaan , Struktur Kepemilikan , Leverage , dan Umur Perusahaan Pada Ketepatan Waktu Pelaporan Keuangan. E-Jurnal Akuntansi Universitas Udayana, 22(1), 572-594. https://doi.org/https://doi.org/10. 24843/EJA.2018.v22.i01.p22 